versatile, si occupò di teoria politica (esordì con un Discorso del perfetto governo della Repubblica di Venezia, 1723), si conquistò una fama internazionale con i suoi esperimenti di "medicina elettrica," curò un'edizione delle opere dell'Ariosto, e fra il 1746 e il 1751 pubblicò in dieci tomi il Nuovo dizionario scientifico e curioso sacro-profano, il più importante dei suoi vari dizionari. Il G. si occupa quasi esclusivamente di quest'opera con una serie di perspicaci sondaggi che mettono in rilievo le componenti ideologiche del Pivati. In rispettivi capitoli vengono studiati gli articoli sul commercio, sull'occultismo, sulla medicina, sulla medicina elettrica, e sugli ebrei: temi che toccano gli aspetti scientifici, religiosi e politici della cultura del Pivati. Da questo studio emerge la figura di un progressista moderato, impegnato in un dialogo con i contemporanei, e non solo italiani, sui problemi del mercantilismo, della superstizione e del fanatismo religioso. Il G. ricostruisce questo dialogo con cura. E il Pivati poteva avere interlocutori pericolosi specialmente in ambienti ecclesiastici. Questo spiega alcune tattiche di "dispositio" che il G. studia egregiamente. Per esempio: nell'articolo astronomia il Pivati sostiene le tesi tolemaiche; poi nell'articolo mondo accetta le tesi copernicane: e come prova il G., non si tratta di conversione avvenuta nel periodo decorso fra la pubblicazione degli articoli, ma a prudenza di uomo che conquista senza creare scandalo.

Nel complesso un lavoro originale ed elogiabile che ha il merito di presentarci un episodio di quella cultura arcadico-razionalista che con il tempo avrebbe modificato la "mentalità" italiana e reso meno potenti le forze oppressive.

\title{
PAOLO CHERCHI
}

University of Chicago

ALBERT N. MANCINI. Romanzi e romanzieri del Seicento. Napoli: Società Editrice Napoletana, 1981. Pp. vii +281.

In the context of the renewed interest in the Italian seventeenth century novel, Albert N. Mancini has collected in this volume six essays independently published between 1966 and 1981. Nevertheless, the volume exhibits a fundamental unity, and the essays may easily be seen as a sequence of related chapters of the same study, divided into two main sections: first, a search for the "Lineamenti di una storia delle poetiche del Seicento," (chapters 1-3) which is mostly theoretical; second, an analysis of particular "Modi e strutture dell'invenzione romanzesca del Seicento," (chapters 4-6) which provides specific examples of the practical application of the ideals and principles previously examined.

The volume opens with "Aspetti e caratteri delle poetiche romanzesche nel Seicento italiano," in which the author underlines the fact that up to 1640 the Italian novel shows a clearly established pattern of themes and characters, although it still lacked a systematic theory. However, it is possible to trace a line of poetics through the statements made by the various writers in the prefaces to their works. Usually, these prefaces deal with the specific aims of the novel and its relations with epic poetry and history. As for the former, the novelists insist on the moral and teaching as- 
pects (which determine the exemplary nature of the protagonists and allow the author to introduce his comments into the narrative context). Still, the novels' tendency to entertain is quite obvious, and, from this point of view, we may add that they share common principles concerning literature typical of the Baroque movement. As for the relations between the novel and the epic poetry, elements derived from sixteenth century discussions of the latter are soon adopted for the former in order to raise its status. Among others, the insistence on verisimilitude is important, even if the various writers seem more concerned with fanciful and marvellous details than structural and psychological coherence. It indicates a transition from a kind of Hellenistic and chivalric novel to one where heroic and amorous adventures are set in an historical background, with continuous reference to contemporary matters and interests. In conclusion, Prof. Mancini suggests that the success of the novel in the seventeenth century should be seen as a consequence of the decline of literary genres such as tales and epic poems, and of the Baroque tendency to explore genres with no, or little, literary tradition.

The second chapter ("Tendenze tecnico-stilistiche nelle poetiche romanzesche del Seicento") focuses on the aspects of poetics dealing with the writers' choice of form and style for their works. Quite relevant in this chapter is the attention given to the variety of attitudes connected with the different environments in which the authors operated. Thus, for instance, Ferrante Pallavicino, a member of the Venetian Academy degli Incogniti, insisted on the principle that the artistic level of a work is founded on its ability to satisfy the needs of the taste of its times and to please the public, rather than in the approval of the experts. Therefore, according to the principles of the followers of Marino, he considers best the most elegant style, and the greater the writer, the more he will be able to create new and complex ornaments. On the other hand, Luigi Manzini, another member of the same Academy, but closer to the cultural environment of Bologna, preferred a form less ornate, but full of conceits and structured in its sentences on the model of Seneca. Notwithstanding, both Andrea Genuzio, of the Neapolitan Academy degli Oziosi, and Anton Giulio Brignole Sale, of the Genoese Academy degli Addormentati, attritubed the more ornate style of their writings to contemporary taste. In conclusion, the literary aspects of these works increase the dangers of technicality which is peculiar to seventeenth century inspiration. The efforts to elaborate the language often seem artificial, and it is quite difficult to determine when rhetorical devices are used artfully and when they represent a conscious stylistic choice.

The third chapter ("Prosa e narrativa nelle poeticle romanzesche del medio Seicento") examines first Tommaso Stigliani's negative attitude towards contemporary writers and his admission that Marino and Biondi, together with their followers, are mainly responsible for the decline of poetry and prose respectively, a judgement shared by many others, which is in itself a recognition of the relevance assumed by the novels. About the second quarter of the century, the writers of this genre openly showed their literary tendencies determined by the taste of their public, that is, intellectuals and academic amateurs belonging to aristocracy and upper middle classes. Towards the middle of the century, however, it is possible to sense an opposition to the excess of literary devices. Giovanni Ambrosio Marini, author of Colloandro, charted in the three subsequent versions of his novel progressive observations on the limits of contempo- 
rary writers (whose works are either too long or too short, too ornamented or too bereft of inventive power). According to him, it is better to attract the reader with the novelty and variety of the topic, rather than with the style; and, one should not omit the aim of moral profit. Other writers shared, in varying degrees, Marini's concerns (Corbelli, Carmeni, Frugoni, Pamini) so that by the middle of the century we can find different solutions in different authors, under the influence either of personal choice or their social and literary environment. Finally, Bernado Morando was more clearly opposed to the artificial style and interested in a credible content which should join pleasure with profit.

In the fourth chapter, the first of the second part of the volume, Prof. Mancini analyzes some "Costanti tematiche e formali del romanzo eroicocavalleresco del primo Seicento." In the recent revival of studies on this phenomenon he senses two main limits: an excessive tendency to examine the novels on the basis of geographical and regional distribution, and a preoccupation to compare them with other works written in totally different periods. He prefers to limit the analysis to some of the thematic and narrative structures of the avventuroso-galante novel. From this perspective one may notice the genre's variety and the presence in it of many literary forms (epic and lyric poetry, the short story, history and epistles among others), developed into two main themes, one adventurous and heroic, the other amorous and gallant. The equilibrium between the various components is determined by the psychological expectations of the public, which uses the text as an escape from daily life. The structure is usually provided by the mixture of a political intrigue and a love story, either created by the writer or borrowed from history. The success of this kind of fiction between 1630 and 1680 was helped by the decline of the late sixteenth century chivalric poems and Spanish and French novels. Love, war and chivalric are the ideals of the main characters in these novels, which function as guides to a heroic life and social and wordly virtues. The protagonists always move and act in relation to a court which reflects contemporary life and habits under the influence of the same principles and criteria, thus limiting their individual characterization. A typical situation is the presence in a hostile court of the hero under false name or in disguise, allowing the author to create a tension between reality and pretence. Often the character himself does not even know his real identity: the reader might be informed of it (in which case his interest will rest on how the author will solve the recognition) or not (and will join the protagonists' rejoicing in the happy ending). In the sequence of events, the hero may be indifferent to fortune's reverses; but, usually, his feelings are not really elaborated by the author who is more involved with the novelty of the situation than with the psychology of his protagonists.

In the last two chapters, Prof. Mancini dwells on motives, narrative structures and characteristics of some novels which reflect a less abstract and more concrete approach, somehow connected to contemporary reality. Thus, in "La trilogia di Glisomiro di Girolamo Brusoni" he examines three novels of the Venetian writer as a "mélange" of life and literature, in an effort to represent more clearly historic reality, society and customs. The subject matter, divided into three seasons - winter, summer and fall - and set around the Venetian lagoon and its nearby territories, is expressed in the form either of action or narrative and tries to describe the environment around the figure of the protagonist. The trilogy, (writ- 
ten between 1657 and 1662) is seen as evidence of the crisis of the adventurous-courtly novel which flourished in the Venetian area in the first half of the century, that tried to mix heroic-chivalric motives with contemporary history and politics.

In "Motivi e schemi picareschi ne 'll D. Antonio o il birba finto principe' " by Santi Nicoletti (a work published in Brescia in 1698 and 1699), the author analyzes resemblances and differences within the Picaresque tradition and the elements derived from the contemporary cultural and literary code. The plot of the novel (extremely simple when compared to the others) deals with the enterprises and crimes of the protagonist, who lives in a corrupt environment, displays a very utilitarian conception of life and soon understands the way to make use of his contemporaries' weaknesses. Full of physical and intellectual qualities but of poor and ambiguous morality, he declines throughout the novel into psychological and ethical degradation, elements which point to an ideal rather than an historical biography. The work, which anticipates several aspects of the eighteenth century novel, is still tied to the Baroque because of the author's partiality for sensational attitudes and situations, and because of his stylistic preference for metaphor, conceits, wordplays, etc. mixed with popular and dialect expressions.

Finally a useful appendix provides the summaries of eight novels of the heroic-chivalric type, summaries that confirm, with the overlapping of many situations and different episodes involving a large number of characters, the very complex structure of this kind of literature, extremely difficult to follow and almost impossible to remember.

Remarkable in this volume is the consistency of the critical attitude which led the author in his studies through so long a period of time. In a series of collected essays one seldom finds this kind of coherence, which shows Prof. Mancini's faithful and critically attentive dedication to his topic. Notwithstanding some minor, unavoidable repetitions, this stimulating book illustrates Prof. Mancini's wide research into original sources neither particularly exciting as reading nor easily accessible to scholars. Also, the variety of authors discussed and the quantity of the bibiographical references (often difficult to locate but very carefully updated) make this work a substantial contribution to the study of seventeenth century Italian literature. It is certain that Prof. Mancini's effort will be very much appreciated by all those who consider the study of the cultural context of literature revelant to a better understanding of historical and literary movements.

ANTONIO FRANCESCHETTI

University of Toronto

LAMBERTO PIGNOTTI, STEFANIA STEFANELLI. La scrittura verbo-visiva. Le avanguardie del Novecento tra parola e immagine. Milano: Espresso Strumenti, 1981. Pp. 224

Come si è visto sempre più spesso nei recenti saggi critici sulla neo- avanguardia italiana degli anni Sessanta e Settanta, la cosiddetta "avanguardia storica" del primo Novecento va ricordata e riveduta per molti dei suoi 